\title{
Margaret McCartney: Medical school interview courses are needless and unfair
}

\author{
Margaret McCartney general practitioner
}

Glasgow

What preparation did you do for your medical school interview? I went to an open evening with a few lectures for prospective students.

We heard how hard it was to get in, how high the attrition rate was. Some people just weren't cut out for it. I was dimly aware of private schools but hadn't realised how many there were, how confident their progeny were, or how many badges for prefect, head boy, and sports captain could fit on just one lapel of a blazer.

I wonder how many children born poor decided not to apply, perhaps sensing that this environment wasn't for them. Confidence isn't always self generated but may be environmental. And good evidence shows that current systems fail to ensure that medicine recruits a wide enough selection of society to reflect it.

Less affluent children are less likely to apply to medical school and get in. ${ }^{1}$ Only $7 \%$ of pupils in the UK are educated privately, but they compose a quarter of medical students doing their first degree. ${ }^{2}$ Children who attended private schools are more likely than those from state schools to become surgeons, whereas GPs are more likely to come from state schools. ${ }^{3}$ This doesn't tell us cause or effect, but attention should be paid when considering the needs of the future workforce.

What would make poorer children feel more welcome? Start with a clear statement from all medical schools that all paid-for admission courses are unnecessary. We have a thriving marketplace, jostling with a surreal panoply of "medical interview preparation" courses (one including a "parent consultation," costing $£ 270$ for an hour's consultation using doctors and "former medical admissions tutors") $)^{4}$ or "unique personalised coaching" (interview practice, at £200). ${ }^{5}$

Do we have evidence that personal statements or interviews find better future doctors?

In a paper copy of The BMJ I've been bemused-nay, dismayed - to find leaflets advertising a company called MediPrep. Working in partnership with BMJ and a private university, the BPP School of Health, MediPrep boasts that "100\% of our students have gained medical school places" and offers to "help you create a personal statement to be proud of, written in the right way, ticking all of those application boxes to ensure you get noticed from the crowd." For a mere 500 quid, that is.

Sure, they offer some bursaries to children who can get their head teacher to confirm their household income. But this can only attempt to excuse inequality, sanctioned by access to disposable income. An easier way to level the playing field may be to raze it. Do we have evidence that personal statements or interviews find better future doctors? Do these courses instead risk producing doctors who are compliant with whatever dogma is in vogue rather than finding people capable of challenge, independence, and dissent?

A great many initiatives work hard, usually voluntarily, to help able students who might have considered medicine but are environmentally disadvantaged. Fabulous. But can we please not undermine them all with a needless, unfair industry?

Competing interests: See www.bmj.com/about-bmj/freelancecontributors/margaret-mccartney.

Provenance and peer review: Commissioned; not externally peer reviewed.

Follow Margaret on Twitter, @mgtmccartney

1 Steven K, Dowell J, Jackson C, Guthrie B. Fair access to medicine? Retrospective analysis of UK medical schools application data 2009-2012 using three measures of socioeconomic status. BMC Med Educ 2016;357:11. doi:10.1186/s12909-016-0536-1 pmid:26759058.

2 White C. Private school pupils still disproportionately represented in medical colleges. BMJ Careers 1 Oct 2013. http://careers.bmj.com/careers/advice/view-article.html? id=20014822.

3 Rodriguez-Santana I, Chalkley M. Centre for Health Economics, University of York. The socioeconomic and demographic characteristics of United Kingdom junior doctors in training across specialties. Dec 2015. https://www.york.ac.uk/media/che/documents/ papers/researchpapers/CHERP_119_junior_doctors_training_specialities.pdf.

4 Dukes Education. http://dukesconsultancy.com/medical-applications-0.

5 ISC Medical. https://www.medical-interviews.co.uk/product/one-to-one-interview-practicemedical-school.

Published by the BMJ Publishing Group Limited. For permission to use (where not already granted under a licence) please go to http://group.bmj.com/group/rights-licensing/ permissions 
